\title{
Perspectives of Pre-School Teachers on Television Viewing in Determining Behavioral Tendencies among Preschoolers in Kenya
}

\author{
Adhiambo Cellestine
}

\author{
Masters student, Department of Early Childhood Education, \\ Jaramogi Oginga Odinga University of Science \& Technology, \\ Bondo-Kenya

\section{Dr Benson Charles Odongo} \\ Department of Early Childhood Education, \\ Jaramogi Oginga Odinga University of Science \& Technology, \\ Bondo-Kenya

\section{Dr Peter J.O. Aloka} \\ Department of Psychology \& Educational Foundations, \\ Jaramogi Oginga Odinga University of Science \& Technology,
}

Bondo-Kenya

Doi: 10.2478/jesr-2018-0013

\section{Abstract}

The present study determinedperspectives of pre-school teachers on television viewing in determining behavioral tendencies among preschoolers in Kenya. The study was guided by Albert Bandura's Social Learning Theory. The target population of the study comprised of one head teacher, three ECDE teachers. Saturated sampling technique was used to sample 3 pre-school teachers.15 preschoolers were sampled using Purposive sampling technique after putting them into three stratus of those from rural, urban and more urban areas, which comprised of 20, 20 and 10 preschoolers from each stratum respectively. The researcher used interview schedules, observation schedules and focus group discussion guides as the study instruments. Validity of the instruments was ensured by seeking expert judgments of the supervisors and trustworthiness of qualitative data was also ensured. Thematic analysis was employed to analyze the data. The study findings revealed that there was increased physical aggression among children. Though; some children were also empathetic and loving. The finding also established an increased engagement in indoor and outdoor activities by the children. The results further showed an increased language development among children. Moreover, there was also enhanced mutual relationship realized among the learners. The study recommended that; pre-school teachers should encourage parents to engage their children in watching educational TV programs while at home, this was because the study findings revealed that children who watched television had well developed language and also performed well academically. Parents should limit TV viewing time per day and totally banning programs that are too violent or offensive by checking the television listings and programs ahead of time to ensure age appropriate programs, this was because the study findings revealed that children had long hours of TV watching.

Keywords: perspectives; pre-school teachers; television viewing; behavioral tendencies; preschoolers; Kenya

\section{Introduction}

There has been a lot of development as far as means and channels of passing information from one person to another are concerned. These developments are meant to suite people of the times, starting from face to face communication to electronic media means of communication. In fact, the 
globalization and propagation of media are among the main factors that have defined and shaped the current generation of young people. El- tawila Sahar (2003) observed that in many countries, children had access to greater portion of multimedia alternatives than ever before ranging from newspapers and magazines; radio stations; satellite and cable TV channels; the internet, computer and video games. In relation to this, Marshall (2004) pointed that, with every change in the way people communicate in various cultures, there is a new struggle over meaning, significance, knowledge and power: thus giving the society an opportunity to think through whether use of media is shifting and changing the way people relate to it and one another.

The study was informed by Social Learning Theory by Bandura, (1977). Social learning entails direct experience or observation and modeling. Some key elements in this theory are attention, retention, motor reproduction and motivation. According to Bandura, attention to an event is influenced by characteristics of the observer. For example repeated observation of an event by a child who has been paying close attention should increase learning of either a negative or positive behavior. Retention refers to how well an individual remembers behaviors that have been observed. Motor reproduction is the actual behavioral enactment of the observed event. For example some children can accurately imitate a behavior after observing it but others need to experiment. (Bandura, 1977).This theory was relevant to the present study in that, preschoolers who were the centre of interest are socialized as they observe television and computer movies, listen to radio not forgetting use of cell phones to access information. Through this they interact in a very special way with media especially actions or language performed or broadcast over the media both good and bad to an extent of being displayed in their behaviors. This may be necessitated by the effects of attention, retention, motor reproduction and motivation aspects of this theory.

Mbutor (2015) did a study in Britain and revealed that, International students watched British Television often and that they watched news programs more than any other genre to update with events happening in their countries of origin and their host countries. The study also revealed that the effects of British television on International students improved their speaking skills and gave them an in-depth knowledge of the British culture. In another study, Haagsma, Pieterse and Peters (2012) carried out a study on Dutch adolescents and revealed that gaming in general is a wide spread and popular activity among the Dutch population. Browser games and other offline casual games were reported to as the most popular type of games. Online games were played by a smaller part of the respondents yet more time was spent on online games as compared to browser games. Male adolescents seemed more vulnerable than their female counterparts to developing problematic gaming habits. Strasberg, McKinnon, Sustaita and Rollo (2013) did a study in the South-western US, reported that $20 \%$ of the participants reported they had ever sent a sexually explicit image of themselves via cell phone, over $25 \%$ indicated that they had forwarded such a picture to others. Of those reporting having sent a sexually explicit cell phone picture, over a third did so despite believing that there could be serious legal and other consequences attached to the behavior. Adeniyi(2015) did a study in Nigeria, revealed that quite a large number of children followed specific patterns in viewing television. The study disapproved the general belief that television wastes students' time and result in poor academic performance. The study revealed that patterned television viewing could be rewarding and could enhance chances of students' performing excellently. Ngugi (2015) revealed a relationship between television viewing and academic performance among students. Wanjiru (2011) revealed that Television watching affected oral development in English of pre- school children. They were able to develop faster in English speaking than those who did not watch television. Moreover, television watching improved the listening ability of pre-school children as they were keen in their examinations.

Samora (2012) reported that $72 \%$ of all Ghanaians had mobile phones in their homes and $86 \%$ own radio nationally, while Kenyans had $71 \%$ mobile phones at home and $87 \%$ homes had radio. In connection to this, radio and television are the most accessible communication and entertainment platforms in both Kenya and Ghana. Television programs from channels such as Kenya Television Network (KTN), Nation Television (NTV) and Citizen Television have been known to expose children to such captivating programs like soap operas, movies, cartoons and African movies which have turned addictive to children since they are quite dramatic and have the power to fix the young mind on the screen for long hours (Musyoka, 2013). Television has become common 
means of communication in Kenya reaching large audience with no personal contact between individuals sending the information and those receiving it (Thomas, 2000). This means, the targeted audiences are many with all areas included. Bondo Sub-County is located relatively in an urban setup where almost each household has a TV set. As a result the preschool child is predisposed to violent programs which later reflect in their violent behavior especially among themselves as had been recently observed by the researcher during a physical Education lesson where one of the children intentionally kicked a playmate. More so, a report from Bondo Sub-County DICECE Office (2015) revealed a number of cases of deviant behavioral tendencies among preschoolers.

\section{Research Methodology}

The research adopted a qualitative approach with a single case study research design. Stake (1995) states that; a case study research is concerned with the complexity and particular nature of the case in question. Single case study research design involves extensive study about a person or group of people or a unit aimed at generalizing over several units. In this design the focus was based on a special unit (Jacobsen, 2002). The design can also be used to rigorously test the success of an intervention or treatment on a particular case and to also provide evidence about the general effectiveness of an intervention using a relatively small sample size. In this study, the target populations included 3 ECD teachers and 50 preschoolers. The preschoolers were put into three subgroups of those from rural (20), urban (20) and more urban (10) areas respectively, there after $30 \%$ of preschoolers from each stratum was purposively sampled which gave a total of 15 preschoolers forming the sample. This study employed four tools of data collection. Observation schedule was used on the sampled preschoolers and interview schedules for pre-school teachers. To enhance content validity the researcher sought expert judgment from the academic supervisors to appraise the instruments. The aim of trustworthiness in a qualitative inquiry is to support the argument that the study results are worth paying attention to (Lincoln and Guba, 2000).Credibility was ensured through purposive and saturated sampling techniques of individuals serving as the sample along with observations, interviews and discussions during data collection. (Lincoln and Guba, 2000).To ensure transferability, the researcher provided sufficient contextual information about the study sites which enabled the readers believe to be similar to the one described in the study. Making them to relate the research findings to their own situations (Lincoln and Guba, 2000). The researcher ensured dependability by in-depth methodological description to allow for the study to be repeated (Lincoln and Guba, 2000). Credibility was ensured by detailed description of the phenomenon under scrutiny. In addition, each person who was approached was given an opportunity to decide whether or not to participate in the study so as to ensure that the data collection session only involved those who were genuine and willing to take part and to offer data freely (Shenton, 2004). Transferability was ensured by providing background data to establish the context of the study and detailed description of phenomenon in question to allow comparisons to be made. Information about the fieldwork site was given to allow the findings to be applied to other situations (Shenton, 2004). In order to ensure dependability, the processes within the study were reported in detail, thereby providing an opportunity for on coming researchers to repeat the study, but not necessarily to gain the same results. In depth coverage allowed the researcher to assess the extent to which proper research practices had been followed (Shenton, 2004).

\section{Findings $\&$ Discussions}

The study investigated the perspectives of pre-school teachers on Television viewing in determining behavioral tendencies among preschoolers. The study employed qualitative data which was collected through interviews and observations. The data collected from the preschool teachers and the observations done by the researcher generated the following themes; Increased physical aggression, increased empathy, increased engagement in indoor and outdoor activities, enhanced language development and enhanced mutual relationship. 


\subsection{Increased Physical Aggression}

Physical aggression involves fighting one another due to anger without realizing the impact. It was reported that there was a lot of fight amongst the children. This wasconfirmed during the school observation sessions. The researcher spotted some children fighting over a tyre during an outdoor activity. One of the respondent remarked;

I had to rush one of the children to the hospital when he was hit on the nose by one of them during a struggle for a ball. The boy bled a lot and I had to convince the parent that it was an accident. What amazed me was that the culprit cried but when asked, he said that he was also hit and paid back but he never knew he would bleed (T2).

From the above excerpt it is clear that there is aggression among children, the nature is intentional since the child who hit the fellow and bled reasoned that he had to hit back after also being hit. During the researcher's observation the same was witnessed when one child who had a tyre during an outdoor activity refused to give it to the other who in return beat her up. Ibukunoluwa (2014) also found out that there was violence and aggression in children especially girls. Another respondent had this to say;

I am tired with this child; he likes fighting and beating others here at home and at school. Am often called to school over his fights with fellow children (P12)

From the excerpt during Focus group discussion, respondent P12 suggested that physical aggression was rampant in young children both at home and school. This seemed to have troubled the parents until they lacked words to express their anger over the same. Maina (2013) in Kenya also agreed that there was a correlation between exposure to TV viewing and aggressive behaviors. Boys were noted to be aggressive after violent TV exposure.

\subsection{Increased Empathy}

This refers to the ability of one to relate to another and share their experiences. It involves placing one's self into another's shoes and feel what they are feeling. Qualitative data collected revealed that some children were empathetic and took others problems as was remarked by a respondent;

A parent one day reported to me that her child always cry for her to put for her more tea and snacks to share with a friend who never carries. In most cases these children share and eat together during snacks time. The child who carries snacks even gives the bigger share to the friend (T1).

It is seen from the above respondent T1 that despite aggression being displayed by some children as seen earlier, there were those who were empathetic and loving. From the above respondent the child who empathizes clearly tells the mother why she wanted more to carry to school. The implication could be that the children learn giving and sharing from home. Bandura (1977) also concurs that children learn by modeling adult figures around them.

\subsection{Increased Engagement in Indoor and Outdoor Activities}

This entails active involvement in activities which are mostly done outside the classroom situation. Children are expected in normal circumstances to be active in almost all activities unless otherwise. Children who are involved in both out and indoor activities are growing towards holistic development. During the researcher's observations of children at school, most children were seen to be more active especially during outdoor activities. This observation was also echoed by one of the respondents who remarked;

Everybody will rush to the field with joy, even those who never participated in classroom activities will rush for the outdoor activities (T2) 
The sentiment of T2 implied that children enjoyed the outdoor activities more than the indoor activities. This could be because of the freedom during these activities and probably because of the varied play materials. More so, this session breaks the boredom of the classroom activities. Naturally play is children's food; just as the saying which goes "work without play makes Jack a dull boy." HaagsmaPieterse and Peters (2012) also agrees that gaming in general is wide spread and popular activity. On the other hand another respondent argued that television viewing also enhanced children's performance and participation in indoor activities and thus remarked that;

Just before the normal class sessions start most children enjoy the free choice activities as they interact with the displays and get time to appreciate their previous work done during classroom activities (T3)

The sentiments of T3 imply that children enjoy self directed activities as opposed to those that they are directed to. Manipulation is also an aspect that most children enjoy because they get to interact with realia which makes learning more real hence enjoyable and interesting. Wanjiku (2014) in Kenya also concurred and said that TV consumed time that preschoolers needed for other activities.

\subsection{Increased Language Development}

During the observations and interviews it was noted that there was good command of language in children. Most children were able to communicate well and speak in both Kiswahili and English. They were able to express their views and air their grievances to the teachers and care givers well. More so they were able to communicate among themselves and understand one another. The same sentiment was echoed by one respondent and remarked;

Most children performed well in language activities and were able to communicate well in both Kiswahili and English. Majority of the children are able to follow simple instructions and express their needs like asking for permission to go to the toilet and such like (T3)

The reflection of T3 implies that TV viewing enhanced language development in children. Most children were fluent in spoken languages and had no problems in self expression especially their needs. Adenyi (2015) who argues that TV viewing does not waste children's time as believed by many but enhances chances of excellent performance. The same is supported some how by Ngugi (2015) who said that there is a relationship between television and academic performance among children. It is only challenging that the relationship could be positive or negative. But Wanjiru (2011) Confirmed that the relationship is positive as argued that television viewing enhance the children to develop faster in English speaking than those who do not watch television

\subsection{Enhanced Mutual Relationship}

Relationship is how children connect with one another. At school the connection is expected to be mutual and friendly. Children are expected to be bound with one goal which is learning. The researcher observed that the relationship was generally good except for a few cases which were noticed especially when children struggled for the few resources in and out of classes. One respondent affirmed this and remarked;

My children don't have many problems on how they relate to each other. Majority are up to the school rules which expect them to love one another and never fight in class or in school, apart from few cases who are never settled. Such cases fight one another and at times abuse one another (T1).

The above respondent's sentiment implied that a higher percentage of children connect well with one another and follow the school rules to the latter. However there are a few cases that despite their negative behavioral tendencies are contained in school. Aggression and abuses are some of the aspects noted as contributors to some what the poor relationship realized amongst 
children. Rosempta (2015) revealed an influence of television on children's behavior especially sexual habit and violence. Another respondent also had this to say;

Some children are loving and caring, they empathize with one other especially those who often don't carry snacks. I have a special child in my class and almost everybody in the class feels for him and they help him up in activities (T3)

The above excerpt explains the mutual relationship amongst children especially during activity sessions. Altruism is evidenced when children take care of the special child in their midst and even feed those who don't carry snacks. This kind of attachment is amazing and could be attributed to the child's background and the positive television programs watched at home. On the other hand children could be relating well with one another due to a well developed command of language as remarked by another respondent;

There is good communication amongst the children as they are able to express themselves well.

Many are able to share their interests and make requests whenever in need (T2)

It is clear from the above respondent that communication barrier is a real challenge to relationships. Due to the good communication skills displayed by the children there is mutual understanding and freedom of speech amongst children. Wanjiru (2011) agrees that children who are exposed to television viewing developed faster in spoken English and also had good listening ability. Therefore when a child is able to speak and listens well then relationships are bound to start and develop to higher levels.

\section{Conclusion \& Recommendations}

The study findings revealed that there was increased physical aggression among children. Though; some children were also empathetic and loving. The finding also established an increased engagement in indoor and outdoor activities by the children. The results further showed an increased language development among children. Moreover, there was also enhanced mutual relationship realized among the learners. Current study findings established an increase in physical aggression among children. Many were seen fighting each other on minor issues. However, some children were empathetic and showed love to those who were in need. Further findings revealed that television viewing enhanced language development as majority of the children were able to speak in both English and Kiswahili well. In addition mutual relationship was also realized among the children. The study recommends that parents should be involved in choosing programs which are appropriate for children to watch, rather than allowing them to watch programs that are screened randomly to ensure that they consume age and developmentally appropriate programs. This is because the study findings revealed that most children acquired and modeled western culture from the programs' presenters. Moreover, parents should ensure that they watch at least one episode of the program the child views so they can better understand the content and discuss it with them. If the television program has random violent incidences the parents should discuss alternatives to violent actions as ways to solve problems. This will help curb aggression in children. This is because the study findings revealed that children who are exposed to TV viewing displayed aggression.

\section{References}

Adeniyi, K. A. (2015). Television Viewing Patterns: Implications for Learners in Lagos State Secondary Schools. Journal of Scientific Research and Studies V 2(5), PP 119-125

Bandura, A. (1977).Social Learning Theory. Engle wood cliffs, Prentice Hall New York Berg.

El-tawila, S. (2003). Adolescents Communication Needs: what we know and what we need to Know: Submission to the United Nations Children's funds (UNICEF) Egypt.

Haagsma, C.M., Pieterse, M.E \&Peters, O. (2012).Video Gaming Behavior among the Adolescents and Adults: The Prevalence of Problematic Gaming. Journal of Cyber psychology behavior and social networking, 162-168. 
Ibukunoluwa.(2014).Cartoons Influence towards Violence and Aggression in School Age Children in Nigeria. Med Thesis, Eastern Mediterranean University, Gazimagusa, North Cyprus

Jacobsen, I.D. (2002) Vad, hurochvarfor-Om metodval I foretagsekonomiochandra Samhallsvetenskapligaamnen. Lund: Studentlitteratur

Lincoln, Y.S. \& Guba, E.G, (2000).Naturalistic Inquiry. Newbury Park, CA: Sage Publications Margaret.

Thomas, (2000). Food Advertising on Australian Television: The Extent of Children's Exposure Health Promotion International, Volume 20, Pages 105-112.

Maina, A. W, (2013).Effect of Television Watching on the Behavior of Pre-School Children a Comparative Study of Boys and Girls from Thika Municipality, Kenya.Unpublished Thesis, School of Humanities and Social Sciences, Kenyatta University.

Mbutor, O, J. (2015). The Effects of British Television among Foreign Audience. PhD. Research Anglia Ruskin University, United Kingdom Albert House.

Marshall, P.D (2004). New media Cultures. Buston road, London

Musyoka, R, K, (2013). Factors Influencing Parental Involvement in Children's Academic Achievement in Early Childhood Education in Kathonzweni District. Med Project University of Nairobi.

Ngugi, C.A. (2015).Effects of Television Viewing on Language Performance in Secondary schools in Imenti Central Meru County. Med Research Project, University of Nairobi Kenya.

Rosempta. N,J. (2015).Influence of Electronic Media on Behaviors among Secondary School Children in Mukaa District, Makueni County Kenya.Unpublished Med Thesis, Catholic University Eastern Africa.

Samora, M. (2012, September, $\left.19^{\text {th }}\right)$. The Evolution of Phones: the demise of Mankind. The Press Pg. 2- 3

Shenton, K.A. (2004). Strategies for Ensuring Trustworthiness in Qualitative Research Projects. Education for Information; 22:67-75

Stake, R.E. (1995). The Art of Case Study Research. Thousand Oarks, CA: Sage Publications

Strasberg, D.S, McKinnon, R.K, Sustaita A.M, \&Rullo, J (2013). Sexting by High School Students: An Exploratory and Descriptive Study Archive of Sexual Behavior. Journal of Cyber psychology, (42) Pg. 1521.

Wanjiru, G.M. (2011). Factors that lead to Secondary School strikes in Murang'a.Unpublished Thesis (Med), Catholic University of Eastern Africa.

Wanjiku, N.R, (2014) A Study on Influence of Television Viewing on Children's Social Development among Preschoolers in Thogoto, Kiambu Kenya. Unpublished Med Project, University of Nairobi. 